\section{Wiktor Figiel}

V Liceum Ogólnokształcące

im. gen. Jakuba Jasińskiego we Wrocławiu

\section{Wojciech Ostrowski}

Instytut Filozofii

Uniwersytet Wrocławski

\section{Sebastian Wachowiak}

Szkoła Podstawowa nr 3

im. Mariusza Zaruskiego we Wrocławiu

Mała Uczelnia we Wrocławiu
Katarzyna Kuczyńska

Wrocławskie Centrum Doskonalenia

Nauczycieli

\author{
Aldona Pobojewska \\ Instytut Filozofii \\ Uniwersytet Łódzki
}

\title{
KOMENTARZ DO PROJEKTU PODSTAWY PROGRAMOWEJ NAUCZANIA FILOZOFII W ZAKRESIE PODSTAWOWYM W SZKOLE ŚREDNIEJ*
}

\begin{abstract}
Abstrakt
Tekst jest komentarzem do projektu podstawy programowej nauczania filozofii w szkołach ponadpodstawowych, opracowanym przez interdyscyplinarny zespół nauczycieli szkolnych i akademickich. Autorzy analizują cele projektu oraz zakładane w nim treści kształcenia. Konkluzją tych analiz jest teza o niedostosowaniu programu kształcenia - przeciążonego wiedzą encyklopedyczną i opartego na niespójnych podstawach metodycznych - do celów związanych $\mathrm{z}$ wprowadzeniem filozofii jako nowego przedmiotu nauczania w szkole średniej.
\end{abstract}

\section{Słowa kluczowe:}

filozofia w szkole, podstawa programowa, polska szkoła średnia

\footnotetext{
${ }^{*}$ Uwagi Katarzyny Kuczyńskiej z dnia z 6 XI 2018 roku: komentarz powstał w grudniu 2016 roku - gdy ukazały się projekty podstaw programowych do nauczania poszczególnych przedmiotów w zreformowanej szkole podstawowej a następnie średniej. Reforma została przeprowadzona. Komentowany przez nas projekt edukacji filozoficznej do klas pierwszych szkół ogólnokształcących oraz techników w zakresie podstawowym przeszedł proces legislacyjny niemal bez zmian: kilka czasowników zastąpiono innymi oraz... dodano kilka dodatkowych wymagań szczegółowych (Dokument Podstawa programowa kształcenia ogólnego dla 4-letniego liceum ogólnokształcącego i 5-letniego technikum dostępny jest pod adresem: https://legislacja. rcl.gov.pl/docs//501/12300604/12446876/12446877/dokument299323.pdf). Może gdyby do Akademii nie wpuszczano również tych, którzy nie znają się na arytmetyce, sprawy podstaw programowych z filozofii miałyby się dziś nieco lepiej.
} 


\section{WSTĘP}

Przedmiotem uwag czynimy tylko fragment podstawy (zakres podstawowy), gdyż wyznaczony przez MEN termin konsultacji w okresie wakacyjnym nie umożliwia poddania refleksji całości. Ponadto, o ile o uczestniczeniu w edukacji filozoficznej w zakresie rozszerzonym będzie ewentualnie decydował sam uczeń, to o obowiązkowości przedmiotu „filozofia” w zakresie podstawowym będzie decydował dyrektor szkoły. Tym samym - koncepcja edukacji filozoficznej jako przedmiotu obowiązkowego wymaga uwzględnienia przynajmniej dwóch uwarunkowań, które być może nie są tak naglące, gdy idzie o przedmiot „dla chętnych”. Poniżej wymieniamy owe uwarunkowania oraz przedstawiamy naszą ocenę, w jakiej mierze omawiany projekt je spełnia.

Kolejny szkolny przedmiot obowiązkowy:

1) powinien umożliwiać uczniom rozwój w obszarze szczególnie dla jakości ich życia istotnym, który w ramach dotychczasowej puli przedmiotów obowiązkowych był nieobecny lub marginalizowany;

2) powinien $\mathrm{w}$ swojej strukturze nawiązywać do doświadczeń uczniowskich i wskazywać na realne związki z tymi doświadczeniami:

a) wyposażać w narzędzia pogłębionego rozumienia tego doświadczenia, b) wspomagać nie tylko w rozwiązywaniu podstawowych problemów zawierających się $\mathrm{w}$ tym doświadczeniu, ale także $\mathrm{w}$ świadomym kształtowaniu go; c) czerpać z tego doświadczenia jako źródła inspiracji i uzasadnień metodycznych.

Projekt podstawy programowej następująco uzasadnia obecność filozofii: Głównym celem zajęć z filozofii jest wprowadzenie uczniów $w$ myślenie filozoficzne na bazie filozofii starożytnej Grecji $i$ Rzymu. Przyjęcie takiej koncepcji nauczania filozofii stwarza uczniom możliwość zapoznania się z jednym z najważniejszych źródel kultury europejskiej (śródziemnomorskiej) oraz pozwala rozpoznać jej dziejowe bogactwo i historyczna tożsamość (...) Grecka filozofia wyznaczyła bowiem zestaw zagadnień $i$ wzorców myślowych, które sa obecne w filozofii - czy szerzej: kulturze-europejskiej, w tym polskiej, które zachowaty swoją aktualność aż po dziś (str. 9).

Szczegółowa charakterystyka treści kształcenia nie pozostawia wątpliwości, że Autor/Autorzy główny sens edukacji filozoficznej zdeponowali w wysiłku wyposażenia uczniów w wiedzę encyklopedyczną z zakresu filozofii starożytnej. Opracowali 12 działów/tematów, w odniesieniu do których sformułowali 54 operacyjne cele nauczania, o różnym stopniu złożoności merytorycznej. W „Warunkach i sposobie realizacji” udzielili wskazówki: Na każdy temat nauczyciel powinien przeznaczyć przeciętnie 2 godziny lekcyjne. Pozostate godziny należa do dyspozycji nauczyciela i stuża pogtębieniu, uzupetnieniu lub powtórzeniu materiału. Proste działanie matematyczne odsłania, że skoro jest 12 tematów, to Autor/Autorzy zalecają 24 godziny lekcyjne na ich realizację, czyli 
1080 minut na 54 szczegółowe cele nauczania, czyli średnio 20 minut na każdy cel. I choć być może znajdą się punkty, przy których wskazana jednostka czasowa jest wystarczająca, choćby do tego, żeby podyktować właściwą informację do zeszytu (np. I.1, I.4, I.6, II.1, II.3, II.4), to nie sposób sobie tego wyobrazić przy 6 celach tematu VII, a sprawa staje się zupełnie kuriozalna przy „syntetycznym” celu VIII.5 (wymienia i objaśnia inne ponadczasowe osiagnięcia filozofii Arystotelesa: klasyczna (korespondencyjna) koncepcja prawdy, koncepcja eudajmonii jako celu ludzkiego życia, koncepcja przyjaźni, typologia i ocena ustrojów politycznych).

Lektura treści nauczania (wymagań szczegółowych) odsłania brak ich związku z punktami VI i VII spośród celów kształcenia (wymagań ogólnych). Wśród szczegółowych treści nauczania tylko 5 razy (na 54 cele) odnajdujemy zapis sugerujący samodzielne procesy komunikacyjno-myślowe ucznia, nie będące li tylko prezentowaniem zdobytej wiedzy: III.2, IV.1, V.4, VIII.3, XII.2. Jednakowoż nieco enigmatyczną metodycznie jest formuła „dyskutuje na temat »czy rzeczywistość jest zmienna, czy niezmienna?«, przedstawiając argumenty na rzecz wariablizmu (Heraklit) oraz statyzmu (eleaci)" i analogiczne do niej, zawarte w pozostałych przytoczonych punktach. Po zestawieniu wskazanych celów z celami III.1, IV.4, VI.2, X.4 można nabrać przekonania, że Autorem/Autorami albo powodowała chęć stylistycznego zróżnicowania tekstu, albo dyskusję tak dalece instrumentalizują, że z dyskusją jako metodą pracy na lekcji niewiele ma ona wspólnego. Na tym tle intryguje również zastosowane w celu VII.1 odróżnienie dialogu jako poszukiwania prawdy od dialogu jako środka dydaktycznego. Czy możliwy jest dialog tylko/przede wszystkim jako środek dydaktyczny?

Czteropunktowe zalecenia w „Warunkach i sposobie realizacji” to być może najbardziej wartościowy metodycznie fragment projektu - byłoby rzeczą nieocenioną, gdyby na takich założeniach Autor/Autorzy oparli konstrukcję podstawy programowej. Jednak w zestawieniu z wymaganiami szczegółowymi owe zalecenia dają świadectwo, jak dalece Autor/Autorzy nie rozumieją złożonych relacji między kształceniem umiejętności (np. określonych kompetencji intelektualnych) a przekazywaniem wiedzy jako zestawu uporządkowanych informacji, w tym także najwyraźniej nie rozumieją, czym jest planowanie lekcji i jakie ograniczenia czasowe za sobą niesie. A już zupełnie iluzorycznie zdają się pojmować realną partycypację ucznia w procesach wiedzotwórczych: $\mathrm{z}$ jednej strony napomykają o pobudzaniu uczniów do poszukiwania własnych odpowiedzi, ale najwyraźniej (zob. akapit wcześniej) powinny owe poszukiwania stanowić środek do skutecznej recepcji wiedzy o filozofach/ich koncepcjach. W przytoczonych sformułowaniach wprost, ale także w konstrukcji celów szczegółowych wyraźnie widać, że filozofia w zakresie podstawowym jest przedmiotem, który ma uczniów „wprowadzić do filozofii”. W dodatku do filozofii rozumianej bardzo specyficznie - jako tradycji 
zorganizowanej według akademickich reguł interpretacji i reprodukcji tekstów filozoficznych. Takie ujęcie lekceważy, ignoruje, a w końcu marnuje polski i światowy dorobek w zakresie metodyk nauczania przedmiotów filozoficznych, powstałych nie jako mniej lub bardziej ułomna postać akademickiego kształcenia filozoficznego, ale jako metodyki budowane ze względu na określone cele i jakości pedagogiczne, metodyki dyktowane wolą udzielenia odpowiedzi na pytanie „Co edukacja filozoficzna może dać współczesnemu młodemu człowiekowi?" - także takiemu, który nigdy nie będzie zmierzał do profesjonalnego wykształcenia filozoficznego. Odnosimy wrażenie, że Autor/Autorzy projektu nie tylko nie udzielili jakiejkolwiek satysfakcjonującej odpowiedzi na takie pytanie, ale nawet owego pytania sobie w ogóle nie postawili.

Wydaje się ponadto, że Autor/Autorzy wpisują się w polską tradycję konstruowania i planowania edukacji, wedle której planiści i konstruktorzy wyznaczają niebotyczne zadania dla nauczycieli, choć sami nie czują się w obowiązku zadość czynić wymaganiom własnego autorstwa. Treści nauczania w omawianym projekcie wskazują na gruntowną znajomość zagadnień filozoficznych na poziomie akademickim (choć Autor/Autorzy nie uniknęli błędu merytorycznego: w opisie celu VIII4 przytoczyli zbanalizowane potoczne ujęcie arystotelesowskiej cnoty). W „Warunkach i sposobie realizacji” zaleca się z kolei realizację wieloaspektową, interdyscyplinarną problemów. Jednak ani treści nauczania, ani wytyczne w Lekturach (obowiqzkowych) w najmniejszym stopniu nie wspomogą nauczyciela w „tym właściwym” sposobie nauczania. $Z$ jednej strony zatem podstawa stawia przed nauczycielem wymóg przekazania bardzo dużej ilości informacji, którą Autor/Autorzy wskazali precyzyjnie, $z$ drugiej - dokonania bogatych, twórczych i angażujących uczniów ekstrapolacji materiału na inne obszary kultury (tutaj brak wskazówek chociażby nieprecyzyjnych). Jak więc niniejszy projekt odnosi się do sformułowanych przeze nas warunków związanych $\mathrm{z}$ wprowadzaniem kolejnego przedmiotu obowiązkowego do siatki godzin?

Ad. 1. [Kolejny szkolny przedmiot obowiazkowy powinien umożliwiać uczniom rozwój $w$ obszarze szczególnie dla jakości ich życia istotnym, który w ramach dotychczasowej puli przedmiotów obowiazkowych byt nieobecny lub marginalizowany.] Gdyby móc się odwołać do tego, co w projekcie tylko zasygnalizowane, a zarazem niemożliwie do realizacji przy równocześnie obowiązujących treściach nauczania, odpowiedź brzmi: świetnie. Realizacja zadań wymienionych w 4 punktach zaleceń byłaby okazją do znaczącego poszerzenia kompetencji hermeneutycznych uczniów, służyłaby upodmiotowieniu ich zarówno w obszarze społecznym, jak też poznawczym. Niestety do tej wizji i misji nie dorasta w najmniejszym stopniu wykaz obowiązkowych treści, jak też uzupełniająca go lista lektur. A to treści nauczania są obligatoryjne dla nauczyciela, nie zaś skromne sugestie w zaleceniach realizacyjnych, zwłaszcza 
gdy są sprzeczne $\mathrm{z}$ dyrektywami wynikającymi z treści. Tym samym projekt oceniamy jako konceptualizację anachroniczną, nie wykraczającą poza horyzont erudycyjnego kształcenia, wzorowaną na wykładowym modus operandi kształcenia akademickiego. Wzbogaconą o iluzoryczne ozdobniki stylistyczne, które sugerują, że projekt jest tym, czym nie jest (np. konceptualizacją działań edukacyjnych na rzecz rozwoju krytycznego myślenia i sprawności logicznych).

Ad. 2. [Kolejny szkolny przedmiot obowiazkowy powinien $w$ swojej strukturze nawiazywać $i$ wskazywać na realne zwiąki $z$ doświadczeniem uczniowskim: a) wyposażać $w$ narzędzia pogtębionego rozumienia tego doświadczenia, b) wspomagać nie tylko $w$ rozwiąywaniu podstawowych problemów zawierajacych się $w$ tym doświadczeniu, ale także $w$ świadomym ksztattowaniu go; c) czerpać z tego doświadczenia jako źródła inspiracji i uzasadnień metodycznych].

O zaprojektowaniu tylko pozornie czynnej partycypacji ucznia w działaniu edukacyjnym pisaliśmy powyżej. Jednak projekt abstrahuje od doświadczenia uczniowskiego w szerszym sensie:

a) organizacja treści nauczania nie pozostawia przestrzeni do wykorzystania narzędzi filozoficznych do kształtowania umiejętności analizy indywidualnego i społecznego doświadczenia uczniów, raczej owo doświadczenie jest traktowane jako ewentualne źródło przykładów, które zobrazują koncepcje i poglądy filozofów (np. V4, VIII3, IX3) - wybrane fragmenty historii filozofii pozostają mniej lub bardziej przydatnymi współcześnie fragmentami historii myśli, projekt podstawy nie zakłada ich konfrontacji i/lub dialogu ze współczesnymi dyskursami reprezentującymi doświadczenie różnorodnych grup społecznych; b) waga wybranych problemów w projekcie podstawy jest określana $\mathrm{w}$ odniesieniu do ich obecności $\mathrm{w}$ myśli i pismach wybranych filozofów, czyli jeśli tam znalazły się pytanie $\mathrm{X}$ czy teza $\mathrm{Y}$, to warto je rozpatrywać i sprawdzać ich aktualność; nurtujące współczesnych młodych ludzi problemy pojawią się zatem, ale wyłącznie jako ewentualna „ilustracja” ponadczasowości starożytnych konceptów, nie zaś jako same w sobie godne refleksji; c) projekt podstawy zadziwia tym, że nie sposób w nim odnaleźć śladów współczesności, równie dobrze mógłby być projektem przedkładanym 3 lub 2 dekady temu; nie tylko zaplanowane treści nauczania abstrahują od specyficznie współczesnych elementów doświadczenia ludzkiego, ale także we fragmencie „Warunki i sposób realizacji” nie odnajdziemy różnorodności metodycznej (nomen omen „Warunki i sposób realizacji”), która powinna wynikać zarówno ze świadomości wielości kontekstów pedagogicznych, jak też uwzględnienia specyficznych form poznawania i doświadczania świata przez młodych ludzi (np. popkultura, internet). Być może Autor/Autorzy i tę kwestię, jak wszystkie pedagogicznie doniosłe, pozostawiają w gestii nauczyciela, samym sobie pozostawiając zadanie przypilnowania, aby na lekcjach pojawiła się dostateczna ilość „ponadczasowych prawd filozofii”. Przy czym katego- 
ryczne odróżnianie meritum (wiedzy przedmiotowej) i metodyki (sztuki przekazywania wiedzy przedmiotowej) jest w swoim pozytywistycznym rodowodzie nie mniej anachroniczne niż dokonany w projekcie podstawy wybór treści nauczania. Związki między formą i materią w nauczaniu są subtelne i złożone - i chyba szkoda, że projekt podstawy, który duży akcent kładzie na znajomość koncepcji Arystotelesa, nie korzysta z jej owoców do przyjrzenia się samemu sobie.

\section{NOTY O AUTORACH}

Wiktor Figiel - nauczyciel przedmiotów filozoficznych w gimnazjum oraz liceum. Współpracuje przy filozoficznych inicjatywach edukacyjnych dla młodzieży (Anima(cje) Filozofii przy Instytucie Filozofii UWr, Jestem z Wroctawia, więc myślę, Porządne myślenie). Trener programu Destination Imagination, opiekun gimnazjalnych i licealnych drużyn debatanckich.

Katarzyna Kuczyńska - konsultant we Wrocławskim Centrum Doskonalenia Nauczycieli, nauczycielka etyki i filozofii pracująca na wszystkich poziomach edukacyjnych. Pomysłodawczyni i inicjatorka różnorodnych przedsięwzięć z zakresu edukacji filozoficznej (np. Anima(cje) Filozofii, Jestem z Wroctawia, więc myślę, Porządne myślenie, Kącik Sokratesa). Autorka pracy doktorskiej z filozofii edukacji, swoje działania teoretyczne określa mianem budowania filozofii sytuacji dydaktycznej.

Wojciech Ostrowski - doktor filozofii, kierownik Pracowni Dydaktyki Filozofii IF UWr, współtwórca projektu Anima(cje) Filozofii oraz innych przedsięwzięć edukacyjnych, autor prac i programów dotyczących nauczania filozofii.

Aldona Pobojewska - profesor doktor habilitowana filozofii, zatrudniona w Katedrze Etyki Uniwersytetu Łódzkiego. Autorka licznych tekstów z zakresu epistemologii i filozofii edukacji, publikowanych $\mathrm{w}$ naukowych czasopismach polskich i niemieckich. Nagrodzona Medalem Komisji Edukacji Narodowej. Rzeczoznawczyni MEN ds. szkolnych podręczników filozofii i etyki. Prezes Stowarzyszenia Edukacji Filozoficznej „Phronesis”. Prowadzi zajęcia z dydaktyki filozofii dla studentów i nauczycieli.

Sebastian Wachowiak - filozof i pedagog; nauczyciel etyki oraz filozofii w publicznej szkole podstawowej oraz niepublicznej wrocławskiej Małej Uczelni; zaangażowany w promowanie i rozwijanie edukacji filozoficznej we Wrocławiu. Dbałość o przedmiotową kulturę dydaktyczną pielęgnuje poprzez udział w rozmaitych projektach na obrzeżach edukacji publicznej (Anima(cje) Filozofii, Jestem z Wrocławia, więc myślę, Porządne myślenie).

\section{COMMENTARY ON THE PROJECT OF THE CURRICULUM OF BASIC PHILOSOPHICAL EDUCATION IN SECONDARY SCHOOLS}

The text is a critical commentary on the project of the curriculum of philosophical education in secondary schools. The authors - an interdisciplinary team of school and academic teachers analyse the goals of the project and the programmed content of teaching. The conclusion of these analyses is that the new curriculum - overloaded with encyclopedic knowledge and based on inconsistent methodology of teaching - is maladjusted to the goals of introducing philosophy as a new subject in secondary schools.

Keywords:

philosophy at school, core curriculum, secondary education in Poland 